Plant Tissue Cult. \& Biotech. 19(1): 61-69, 2009 (June)

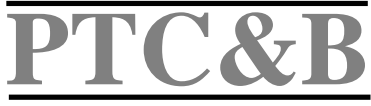

\title{
In vitro Clonal Propagation of Anthurium (Anthurium andraeanum L.) Using Callus Culture
}

\author{
M.T. Jahan, M.R. Islam, Ruseli Khan, A.N.K. Mamun, G. Ahmed \\ and L. Hakim
}

Plant Biotechnology and Genetic Engineering Division, Institute of Food and Radiation Biology (IFRB), Atomic Energy Research Establishment (AERE), Post-DEPZ, Savar, Dhaka, Bangladesh

Key words: Clonal propagation, In vitro, Anthurium andraeanum

\begin{abstract}
High frequency of calli was obtained from leaf and spadix segments of Anthurium andraeanum $\mathrm{L}$. when cultured on $\mathrm{N} 6$ medium containing $2.5 \mathrm{mg} / \mathrm{l} \mathrm{BAP}$ and $0.2 \mathrm{mg} / \mathrm{l}$ 2,4-D in dark condition. The calli were maintained in dark condition on the same medium containing same hormonal supplements by subculturing up to three months but no shoot formation occurred during this period. Leaf and spadix segments derived calli were then tried for multiple shoot regeneration by culturing onto MS fortified with BAP and Kn singly or in combination with NAA in light condition. Best response towards multiple shoot regeneration was observed from both leaf and spadix segments derived calli on MS fortified with $1.0 \mathrm{mg} / \mathrm{l} \mathrm{BAP}$. In this combination an average of 18 shoot buds regenerated from leaf segment derived callus while 14 shoot buds regenerated from spadix segment derived callus. The number of shoot buds increased three to four-folds after subculturing in the same medium. Regenerated multiple shoots were excised and cultured onto half strength of MS with different concentrations of IBA and IAA for root induction. Best root development was obtained in half strength MS containing $1.0 \mathrm{mg} / \mathrm{l} \mathrm{IBA}$. About 85 per cent of the regenerated plantlets survived in natural conditions.
\end{abstract}

\section{Introduction}

Species and hybrids within the Monocotyledonae, genus Anthurium are highly prized as ornamentals for their beautiful showy flowers and exotic foliage. Several species of this genus are grown as houseplants. It is the most popular and economic important genus of Araceae with attractive and beautiful inflorescences (Hamidah et al. 1997). Anthurium is native to the tropics of Central and South America. The structure which is commonly called flower is a combination of spathe (colorful, modified leaf) and hundreds of small flowers on 
the pencil-like protrusion (Spadix). Among the several commercially important Anthurium species, Anthurium andraeanum L. is one of the ten most cultivated ornamental crops for cut flower in the world.

Traditionally seeds or offshoots and nodal cuttings are used to propagate Anthurium and propagation rate is very low. Usually division of offshoots from the main stem propagates Anthurium conventionally. Terminal and single node cuttings are used for their multiplication. Plants derived from seeds show marked variation in color, quality, yield and time of first flowering. Seed viability and germination percentage are also low. Seed are viable only for two three days and germination is as low as 20 to 30 per cent. Hence, there is a need to standardize a quicker method of propagation which may be achieved through in vitro techniques.

In recent years numerous reports on in vitro propagation of different plant species have shown that this technique is suitable for rapid propagation of selected plant species (Bonga and Durjan 1987, Ahuja 1991 and McCown and McCown 1987). There are several reports regarding in vitro regeneration of Anthurium from different explants via organogenesis (Pierik 1976, Geier 1982), somatic embryogenesis (Kuchnle and Sugii 1991, Kuchnle et al. 1992) and callus culture (Pierik et al. 1974). Micropropagation of Anthurium has been achieved with various tissues including leaf, petiole, spadix, seed, lateral bud and shoot tip (Geier 1990; Matsumoto and Kuchnle 1996). Several cultivars of Anthurium were also regenerated using intact lamina and etiolated shoot explants from in vitro grown plantlets (Kuchnle et al. 1992, Kuchnle and Chan 1994).

Anthurium has a great demand in the flower trade market in Bangladesh. The climatic condition, soil type of Bangladesh is very favorable for commercial cultivation of this plant but no significant efforts have yet been made for mass scale propagation of this plant. Considering its importance and to overcome the problem of its propagation through conventional methods, an attempt was made to establish a sustainable and efficient protocol for in vitro clonal propagation of Anthurium andraeanum by using leaf and spadix segment explants.

\section{Materials and Methods}

Three to four months old Anthurium plants (Anthurium andraeanum L.) were collected from local nursery and conserved in the experimental garden of the Institute for obtaining explants. Leaf and spadix segments were used as initial explant source. After collection of these explants from experimental garden, these were washed thoroughly under running tap water for $30 \mathrm{~min}$ and then treated with $0.5 \%(\mathrm{v} / \mathrm{v})$ of Trix (Commercial detergent, Reckitt Benckiser Bangladesh Ltd.) followed by rinsing five times with distilled water. Then they 
were surface sterilized for $1 \mathrm{~min}$ in $70 \%$ ethanol, $8 \mathrm{~min}$ in $1.5 \%$ sodium hypochlorite in which $0.01 \%$ Tween- 20 was added as surfactants.

Explants were cut into smaller pieces and placed on to N6 medium for callus induction. Greenish calli which obtained from these two types of explants were used for multiple shoot regeneration. The following media composition was used in the individual steps of plant regeneration.

Callus induction medium (SCM): Nistch's medium supplemented with different concentrations of BAP and 2iP $(0.5-2.5 \mathrm{mg} / \mathrm{l})$ singly or in combination with $0.2 \mathrm{mg} / 1$ 2,4-D were used for the induction of callus in dark condition.

Shoot multiplication medium (SMM): MS fortified with various concentrations (0.2 $-1.5 \mathrm{mg} / \mathrm{l}$ ) of BAP and $\mathrm{Kn}$ singly or in combination with $0.5 \mathrm{mg} / \mathrm{l}$ NAA was used for multiple shoot regeneration by shifting the callus from dark to light condition.

Root inducing medium (RIM): Half strength of MS supplemented with different concentrations of IBA and IAA $(0.2-2.0 \mathrm{mg} / \mathrm{l})$ were used for root initiation in in vitro grown multiple shoots.

For callus induction and maintenance, cultures were stored in continuous dark condition for three months. For all experiments, $\mathrm{pH}$ of the medium was adjusted to 5.8 and solidified by $0.4 \%$ phytagel and dispensed into culture vessels. The culture vessels containing medium were then autoclaved at $121^{\circ} \mathrm{C}$ and at $1.05 \mathrm{~kg} / \mathrm{cm}^{2}$ pressure for $20 \mathrm{~min}$. Following inoculation, all the cultures were kept in a growth room with $16 \mathrm{hr}$ photoperiod with light intensity of 2000 lux (approx.) from white florescent tube light and at $26 \pm 1^{\circ} \mathrm{C}$. Subcultures were carried out at an interval of five weeks.

Data on induction of callus from two type of explants mentioned above, multiple shoot regeneration from leaf and spadix derived callus, percentage of explants regenerated, number of shoots per culture, mean shoot length, days to rooting, percentage of cultures rooted, number of roots per shoot, average length of roots and survival percentage of rooted plants at natural condition were recorded.

\section{Results and Discussion}

Two type of explants viz. leaf and spadix segments were used for the induction of callus. Callus induction was observed on N6 basal medium supplemented with different concentrations of BAP and $2 \mathrm{iP}(0.5-2.5 \mathrm{mg} / \mathrm{l})$ singly or in combination with $0.2 \mathrm{mg} / \mathrm{l}$ 2,4-D. There was a wide range of variation in percentage of callus induction $(0-85)$ depending on the concentrations and combinations of hormonal supplements (Table 1). Between the two explants, leaf segment appeared to be best for callus induction when cultured on to N6 basal medium. About 85 per cent of leaf segment produced callus on N6 medium 
containing BAP and 2,4-D at $2.5 \mathrm{mg} / \mathrm{l}$ and $0.2 \mathrm{mg} / \mathrm{l}$, respectively (Fig. 1) followed by 80 per cent callus induction in BAP at $2.0 \mathrm{mg} / \mathrm{l}$ with $2,4-\mathrm{D}$ at $0.2 \mathrm{mg} / \mathrm{l}$ and 70 per cent callus production in BAP at $1.5 \mathrm{mg} / \mathrm{l}$ with $2,4-\mathrm{D}$ at $0.2 \mathrm{mg} / \mathrm{l}$. It indicates the role of 2,4-D in callus induction for this ornamental plant. Several earlier workers reported the induction of callus using different explants of Anthurium (Pierick et al. 1974, Pierick and Steemans 1976). Teng (1997) used liquid medium or membrane rafts in the regeneration of Anthurium adventitious shoots. Adelheid et al. (1992) observed somatic embryogenesis in Anthurium andraeanum using whole leaf blade explants, derived from in vitro grown plantlets when cultured on MS supplemented with 1.0 to $4.0 \mathrm{mg} / \mathrm{l} 2,4-\mathrm{D}$ and 0.33 to $1.0 \mathrm{ml} / \mathrm{l}$ Kn.

Table 1. Effects of different concentrations of BAP, 2iP and NAA on callus induction from leaf and spadix segments of Anthurium andraeanum. Thirty replicates were taken for each treatment and data were recorded after five to six weeks of culture.

\begin{tabular}{|c|c|c|c|c|c|c|c|}
\hline \multirow[t]{2}{*}{ Supplements } & \multirow{2}{*}{$\begin{array}{l}\text { Conc. } \\
(\mathrm{mg} / \mathrm{l})\end{array}$} & \multicolumn{3}{|c|}{ Leaf segments } & \multicolumn{3}{|c|}{ Spadix segments } \\
\hline & & $\mathrm{A}$ & B & $\mathrm{C}$ & $\mathrm{A}$ & B & $\mathrm{C}$ \\
\hline \multirow[t]{5}{*}{ BAP } & 0.5 & - & - & - & - & - & - \\
\hline & 1.0 & - & - & - & - & - & - \\
\hline & 1.5 & 35 & $25 \pm 2$ & Cream & 40 & $23 \pm 2$ & Cream \\
\hline & 2.0 & 35 & $35 \pm 2$ & $"$ & 40 & $30 \pm 2$ & $"$ \\
\hline & 2.5 & 35 & $40 \pm 2$ & $"$ & 40 & $36 \pm 2$ & $"$ \\
\hline \multirow[t]{5}{*}{$2 \mathrm{iP}$} & 0.5 & - & - & - & - & - & - \\
\hline & 1.0 & - & - & - & - & - & - \\
\hline & 1.5 & 40 & $20 \pm 2$ & Brown & 40 & $20 \pm 2$ & Brown \\
\hline & 2.0 & 40 & $25 \pm 3$ & " & 40 & $22 \pm 3$ & " \\
\hline & 2.5 & 40 & $30 \pm 2$ & $"$ & 40 & $25 \pm 2$ & $"$ \\
\hline \multirow[t]{5}{*}{$\mathrm{BAP}+2,4-\mathrm{D}$} & $0.5+0.2$ & 35 & $30 \pm 2$ & Green & 40 & $21 \pm 2$ & Green \\
\hline & $1.0+0.2$ & 35 & $45 \pm 3$ & $"$ & 40 & $32 \pm 3$ & " \\
\hline & $1.5+0.2$ & 35 & $70 \pm 3$ & $"$ & 40 & $37 \pm 3$ & $"$ \\
\hline & $2.0+0.2$ & 35 & $80 \pm 2$ & $"$ & 40 & $62 \pm 2$ & $"$ \\
\hline & $2.5+0.2$ & 35 & $85 \pm 2$ & $"$ & 40 & $82 \pm 2$ & ' \\
\hline \multirow[t]{5}{*}{$2 \mathrm{iP}+2,4-\mathrm{D}$} & $0.5+0.2$ & 35 & $25 \pm 2$ & Green & 40 & $21 \pm 2$ & Green \\
\hline & $1.0+0.2$ & 35 & $35 \pm 3$ & $"$ & 40 & $32 \pm 3$ & $"$ \\
\hline & $1.5+0.2$ & 35 & $40 \pm 2$ & $"$ & 40 & $36 \pm 2$ & $"$ \\
\hline & $2.0+0.2$ & 35 & $55 \pm 3$ & $"$ & 40 & $63 \pm 3$ & $"$ \\
\hline & $2.5+0.2$ & 35 & $75 \pm 2$ & $"$ & 40 & $69 \pm 2$ & $"$ \\
\hline
\end{tabular}

A. Days require to callus induction. B. Percentage of callus formation. C. Color of callus.

In the present study, greenish calli were obtained after culturing the explants in $\mathrm{N}_{6}$ medium fortified with different concentrations of BAP and 2iP singly or in combination with $0.2 \mathrm{mg} / 1$ 2,4-D. So the present findings are in agreement with the results of the above authors. 
Though profuse amount of greenish calli were developed by culturing leaf and spadix segments and maintaining them in dark condition for three months no multiple shoots were regenerated from these calli in this condition. So, for the induction of multiple shoots, these two type of calli were cultured on to MS medium supplemented with different concentrations of BAP and Kn (0.2 - 1.5 $\mathrm{mg} / \mathrm{l}$ ) singly or with $0.5 \mathrm{mg} / \mathrm{l}$ NAA by shifting them from dark to light condition. Among the various hormonal supplements, best response towards multiple shoot regeneration was noticed from both leaf and spadix derived callus on MS fortified with $1.0 \mathrm{mg} / \mathrm{l} \mathrm{BAP}$ (Table 2). In this combination, an average of 18 shoots regenerated from leaf segment derived callus (Fig. 2). On the other hand,

Table 2. Effects of different concentrations BAP and $\mathrm{Kn}$ singly or in combinations with $0.5 \mathrm{mg} / 1 \mathrm{NAA}$ on multiple shoot regeneration from leaf segment and spadix segment derived callus of Anthurium andraeanum. There were 30 replicates in each treatment and data were taken after five weeks.

\begin{tabular}{|c|c|c|c|c|c|c|}
\hline \multirow[b]{2}{*}{$\begin{array}{l}\text { Growth } \\
\text { regulators } \\
(\mathrm{mg} / \mathrm{l})\end{array}$} & \multicolumn{3}{|c|}{ Leaf segment derived callus } & \multicolumn{3}{|c|}{ Spadix segment derived callus } \\
\hline & $\begin{array}{c}\text { Explants } \\
\text { regenerated } \\
(\%)\end{array}$ & $\begin{array}{c}\text { Number } \\
\text { of shoots/ } \\
\text { callus }\end{array}$ & $\begin{array}{l}\text { Shoot } \\
\text { length } \\
(\mathrm{cm})\end{array}$ & $\begin{array}{c}\text { Explants } \\
\text { regenerated } \\
(\%)\end{array}$ & $\begin{array}{l}\text { Number } \\
\text { of shoots/ } \\
\text { explant }\end{array}$ & $\begin{array}{l}\text { Shoot } \\
\text { length } \\
(\mathrm{cm})\end{array}$ \\
\hline \multicolumn{7}{|l|}{ BAP } \\
\hline 0.2 & $55 \pm 2$ & $8 \pm 2$ & $6.5 \pm 2$ & $40 \pm 2$ & $6 \pm 2$ & $6.1 \pm 2$ \\
\hline 0.5 & $70 \pm 2$ & $12 \pm 2$ & $7.1 \pm 3$ & $65 \pm 2$ & $10 \pm 2$ & $6.5 \pm 2$ \\
\hline 1.0 & $96 \pm 2$ & $18 \pm 2$ & $8.0 \pm 3$ & $96 \pm 2$ & $14 \pm 2$ & $7.2 \pm 2$ \\
\hline 1.5 & $90 \pm 2$ & $15 \pm 2$ & $7.2 \pm 2$ & $88 \pm 2$ & $12 \pm 2$ & $6.4 \pm 3$ \\
\hline \multicolumn{7}{|l|}{$\mathrm{Kn}$} \\
\hline 0.2 & $50 \pm 2$ & $6 \pm 2$ & $4.8 \pm 2$ & $48 \pm 2$ & $6 \pm 2$ & $4.5 \pm 2$ \\
\hline 0.5 & $75 \pm 2$ & $10 \pm 3$ & $5.6 \pm 3$ & $70 \pm 3$ & $7 \pm 1$ & $5.2 \pm 3$ \\
\hline 1.0 & $90 \pm 2$ & $14 \pm 2$ & $6.0 \pm 2$ & $90 \pm 3$ & $8 \pm 2$ & $5.8 \pm 2$ \\
\hline 1.5 & $85 \pm 2$ & $11 \pm 2$ & $5.7 \pm 3$ & $82 \pm 2$ & $7 \pm 2$ & $5.3 \pm 2$ \\
\hline \multicolumn{7}{|l|}{$\mathrm{BAP}+\mathrm{NAA}$} \\
\hline $0.2+0.5$ & $80 \pm 2$ & $8 \pm 2$ & $5.6 \pm 2$ & $76 \pm 2$ & $7 \pm 2$ & $5.6 \pm 2$ \\
\hline $0.5+0.5$ & $69 \pm 3$ & $6 \pm 2$ & $5.4 \pm 2$ & $65 \pm 3$ & $6 \pm 2$ & $5.1 \pm 2$ \\
\hline $1.0+0.5$ & $64 \pm 2$ & $4 \pm 3$ & $5.2 \pm 3$ & $56 \pm 4$ & $4 \pm 3$ & $4.7 \pm 3$ \\
\hline $1.5+0.5$ & $50 \pm 3$ & $3 \pm 2$ & $4.5 \pm 2$ & $50 \pm 2$ & $4 \pm 3$ & $4.1 \pm 2$ \\
\hline \multicolumn{7}{|l|}{$2 \mathrm{iP}+\mathrm{NAA}$} \\
\hline $0.2+0.5$ & $82 \pm 2$ & $10 \pm 2$ & $5.4 \pm 2$ & $80 \pm 2$ & $10 \pm 2$ & $5.7 \pm 2$ \\
\hline $0.5+0.5$ & $76 \pm 3$ & $8 \pm 2$ & $5.5 \pm 3$ & $75 \pm 3$ & $9 \pm 2$ & $5.5 \pm 2$ \\
\hline $1.0+0.5$ & $68 \pm 2$ & $7 \pm 3$ & $5.1 \pm 3$ & $65 \pm 2$ & $8 \pm 3$ & $5.2 \pm 3$ \\
\hline $1.5+0.5$ & $62 \pm 2$ & $4 \pm 2$ & $4.8 \pm 2$ & $50 \pm 3$ & $4 \pm 2$ & $5.0 \pm 2$ \\
\hline
\end{tabular}

an average of 14 shoots regenerated from spadix segment derived callus (Fig. 3). The regenerated multiple shoots were routinely sub-cultured for further multiplication in the same medium. The number of shoots increased three to 
four-folds when cultured on same medium (Fig. 4). Chand et al. (1999) observed multiple shoot regeneration in Taro (Colocasia esculenta L.) when cultured on MS $+1.13 \mathrm{mg} / \mathrm{l} \mathrm{BAP}$ by using stolon segment. Balachandran et al. (1990) reported in turmeric and ginger that, BAP alone was adequate for multiple shoot regeneration. These two findings are in agreement with the present study, in which BAP was found more effective for multiple shoot regeneration. Callus derived from leaf segment produced comparatively larger number of multiple shoots compared to spadix segment derived callus in the present study.
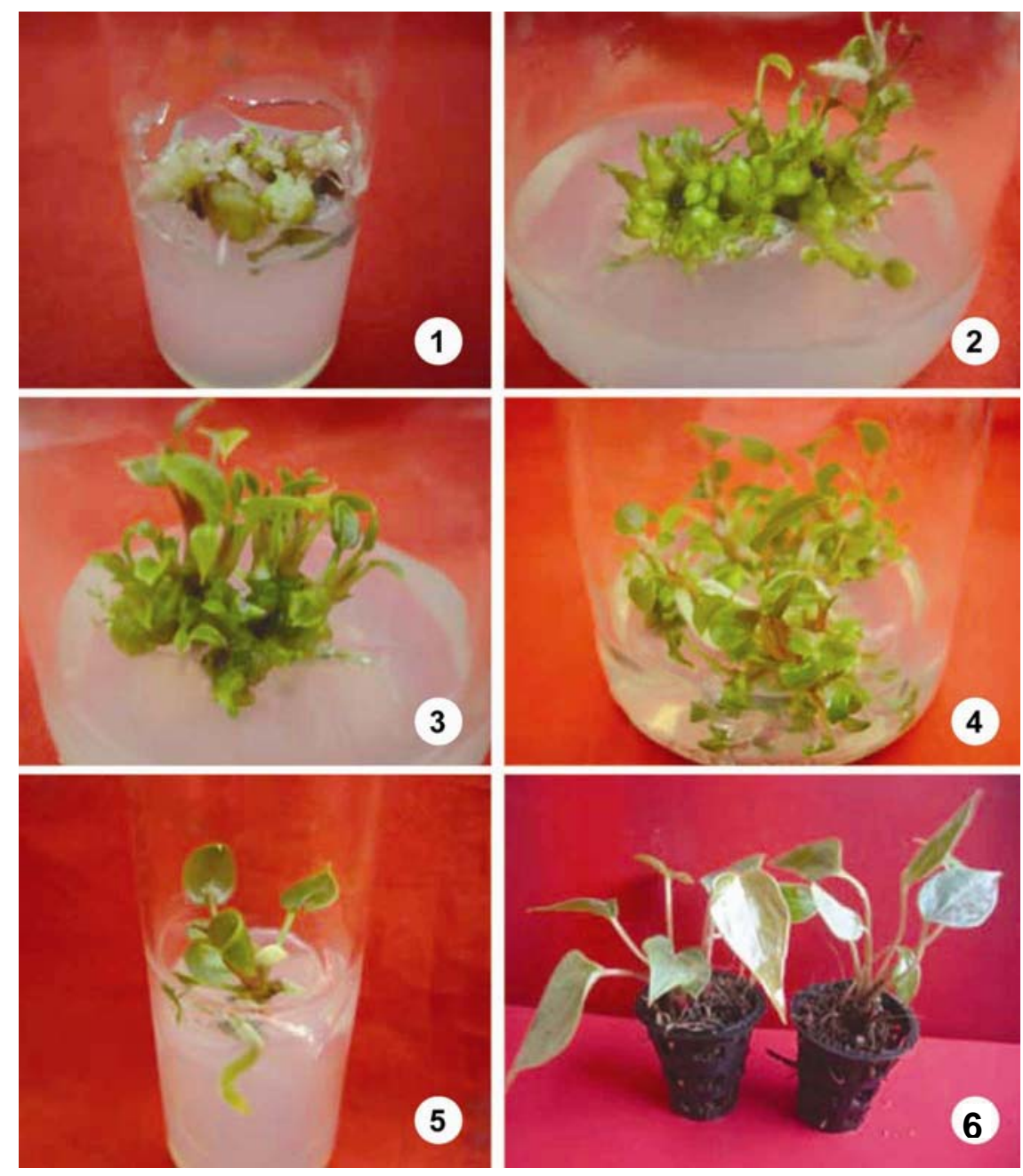

Figs. 1-6: In vitro regeneration of plants in Anthurium andraeanum. 1. Induction of callus from leaf segment in dark condition. 2. Regeneration of multiple shoots from leaf derived callus. 3. Regeneration of multiple shoots from spadix derived callus. 4. Growth and elongation of multiple shoots. 5. Induction of roots from the regenerated shoots. 6. Plantlets established in soil. 
The regenerated multiple shoots, obtained after subculturing of both type of callus did not produce roots spontaneously. For desired root development, the regenerated shoots of 5-8 cm long were separated from the clamp of multiple shoots and they were cultured on to half strength of MS fortified with different concentrations $(0.2-2.0 \mathrm{mg} / \mathrm{l})$ of IBA and IAA singly. In this experiment, the best root development was noticed in the medium containing $1.0 \mathrm{mg} / \mathrm{l} \mathrm{IBA}$ (Fig. 5, Table 3). About 30 - 40 days were required for getting healthy root induction.

Table 3. Effects of different concentrations of various auxins (IBA and IAA) in half strength ( $1 / 2 \mathrm{MS})$ of MS medium on root induction and elongation in in vitro grown shoots. There were 30 shoots in each treatment and data were taken after five to six weeks.

\begin{tabular}{lccccc}
\hline $\begin{array}{c}\text { Supplements } \\
(\mathrm{mg} / \mathrm{l})\end{array}$ & $\begin{array}{c}\text { Days to } \\
\text { root } \\
\text { induction }\end{array}$ & $\begin{array}{c}\% \text { of } \\
\text { cuttings } \\
\text { rooted }\end{array}$ & $\begin{array}{c}\text { Number of } \\
\text { roots/shoots }\end{array}$ & $\begin{array}{c}\text { Average } \\
\text { length of } \\
\text { root }(\mathrm{cm})\end{array}$ & $\begin{array}{c}\text { Survival \% } \\
\text { of rooted } \\
\text { plants }\end{array}$ \\
\hline IBA & & & & & \\
0.2 & - & - & - & - & - \\
0.5 & 40 & 65 & $2.5 \pm 0.3$ & $3.5 \pm 0.2$ & 80 \\
$\mathbf{1 . 0}$ & 30 & 85 & $3.8 \pm 0.2$ & $4.0 \pm 0.2$ & 85 \\
1.5 & 30 & 70 & $3.1 \pm 0.2$ & $3.8 \pm 0.2$ & 85 \\
2.0 & 40 & 60 & $2.4 \pm 0.2$ & $3.2 \pm 0.3$ & 80 \\
\hline IAA & & & & & \\
0.2 & - & - & - & - & - \\
0.5 & 40 & 15 & $2.0 \pm 0.2$ & $2.8 \pm 0.3$ & 80 \\
1.0 & 30 & 35 & $2.2 \pm 0.3$ & $3.7 \pm 0.3$ & 80 \\
1.5 & 40 & 35 & $2.5 \pm 0.3$ & $3.2 \pm 0.3$ & 80 \\
2.0 & - & 15 & $2.0 \pm 0.2$ & $2.5 \pm 0.3$ & 80 \\
\hline
\end{tabular}

Several earlier workers (Al-kalifah et al. 2005, Sinha and Roy 2002, Islam et al. 2001) reported root induction in different type of ornamental plants growing in vitro by using IBA in MS and modified MS medium. It has been reported that IBA is a suitable auxin for adventitious root induction and it was also found superior to IAA or NAA for its more stable nature ((Hutchinson 1981, Litz and Jaiswal 1990).

All the rooted plantlets were subsequently transferred to small pot ( Fig. 6 ) containing sand, loamy soil and coco-peat in the ratio of 1:1:1 and gradually shifted to out door condition. The survival rate is about $85 \%$ (Table 3 ) under natural environment. The protocol thus established can be exploited for commercial propagation of these very attractive ornamental plants in Bangladesh. 


\section{References}

Adelheid RK, Chen FC and Sugii N (1992) Somatic embryogenesis and plant regeneration in Anthurium andraeanum hybrids. Plant Cell Rep. 11: 438-442.

Ahuja, MR (1991). Woody Plant Biotechnology. Plenum Press, New York pp. 373.

Al-kalifah NS, Hadi S and Khan F (2005) Influence of sucrose concentration on in vitro growth of five Rose ( Rosa hybrida L.) cultivars. Plant Tissue Cult. 15: 43-50.

Balachandran SM, Bhat SR and Chandel KPS (1990) In vitro clonal multiplication of turmeric and ginger. Plant Cell Rep. 8: 521-524.

Bonga JM and DJ Durzan (1987) Cell and Tissue culture in Forestry (Vols. 1, 2, 3). Martinus Nijhoff Publ. Dordrecht.

Chand H, Pearson MN and Lovell PH (1999) Rapid vegetative propagation in Colocasia esculenta (L). Plant Cell Tissue and Organ Cult. 55: 223-226.

Geier T (1990) Anthurium. In: Ammirato PV, Evans DA, Sharp WR and Bajaj YPS (eds.) Handbook of plant Cell Culture, pp. 228-252, Mac Graw-Hill, New York.

Geier T (1982) Morphogenesis and plant regeneration from spadix fragments of Anthurium andraeanum. In: Fujiwara (ed.) Plant Tissue Culture 1982, pp. 137-138. Japanese Association for Plant Tissue Culture. Tokyo, Japan.

Hamidah M, Karim AGA and Deberg P (1997) Somatic embryogenesis and plant regeneration in Anthurium scherzerianum. Plant Cell Tissue and Organ cult.48: 189193.

Hutchinson JF (1981) Tissue culture: propagation of fruit tress. In: Proc.COSTED symp. on tissue culture of economically important plants. Rao A.N. (Ed.), Singapore, pp. $113-120$.

Islam MR, Hossain SN, Munshi MK, Hakim L and Hossain M (2001) In vitro regeneration of planlets from shoot tip and nodal segments in Nayantara (Catharanthus roseus L.). Plant Tissue Cult. 11: 173-179.

Kuchnle AR and Chan FC (1994) Agrobacterium-mediated transformation of Anthurium. In: Bajaj YPS (eds.) Biotechnology in Agriculture and Forestry - Plant protoplasts and genetic engineering. Vol. 29 : 215-225). Springer Verlag, Berlin

Kuchnle AR, Chen F and Sugii N (1992) Somatic embryogenesis and plant regeneration in Anthurium andraeanum hybrids. Plant Cell Rep. 11: 438-442.

Kuchnle AR and Sugii N (1991) Callus induction and plant regeneration in tissue culture of Hawaiian Anthuriums. Hor Sci. 26: 919-921

Matsumoto T and Kuehnle AR (1996) Micropropagation of Anthuriums. In: Bajaj YPS (eds.) Biotechnology in Agricultur and Forestry, High-Tech and Micropropagation. Springer Verlag, Berlin (in press).

McCown DD and BH McCown (1987) Northern American Hard Woods. In: Cell and Tissue culture in Forestry, 3, Martinus Nijhoff Publishers, Dordrecht.

Litz RE and Jaiswal VS (1990) Micropropagation of tropical and sub tropical fruits. In: Micropropagation technology and application, Debergh and Zimmerman R.H. (Eds.) Kluwer Academic Publ., Dordrecht. The Netherlands. pp. 247-266.

Pierick RLM (1976) Anthurium andraeanum plantlets produced from in vitro cultivated callus tissues. Physiol Plant 37: 80-82 
Pierick RLM and Steemans HHM (1976) Vegetative propagation of Anthurium scherzerianum Schoot through callus culture. Hor Sci. 4: 291-292.

Pierick RLM, Steemans HHM and Jaj VDM (1974) Plantlets formation in callus tissues of Anthurium andraeanum Lind. Hor Sci. 2: 193-198.

Sinha P and Roy SK (2002) Plant regeneration through in vitro cormel formation from callus culture of Gladiolus primulinus Baker. Plant Tissue Cult. 12(2): 43-50.

Teng W-L (1997) Regeneration of Anthurium adventitious shoots using liquid or raft culture. Plant Cell Tissue and Organ Cult. 49: 153-156. 